\title{
ENVIRONMENTAL TAXES AND EMISSIONS OF POLLUTANTS IN THE EU: EMPIRICAL ANALYSIS
}

\section{Viktor Koziuk}

Ternopil National Economic University, Department of Economics and Economic Theory, Ternopil, Ukraine

\section{Oleksandr Dluhopolskyi}

Ternopil National Economic University, Department of Economics and Economic Theory, Ternopil, Ukraine

\section{Kazymyr Voznyi}

Ternopil National Economic University, Department of Economics and Economic Theory, Ternopil, Ukraine

OMESTE

JEL Category: Q52, Q57, Q58

\begin{abstract}
The system of environmental taxes in EU countries is expected to have an impact on reducing greenhouse gas emissions. Since 2010 the emphasis on environmental regulation has shifted towards the EU 2020 strategy. This research continues the previous author's studies about the environmental measurement of welfare economics. The article tests the hypothesis of the inverse effect of the environmental taxation level on $\mathrm{CO}_{2}$ emissions. The method of cross-correlation analysis was used to confirm the hypothesis. As the dependent variables were chosen emission indicators $\left(\mathrm{CO}_{2}, \mathrm{PM} 2.5 \mathrm{mg}\right)$, and as the independent variables were selected environmental taxes, the share of renewable energy, the number of businesses in the country that have an environmental certificate ISO 14001. The level of environmental taxation has a significant impact on the amount of $\mathrm{CO}_{2}$ emissions in the direction of their reduction. The share of renewable energy in final consumption also has a significant impact on the dynamics of changes in the amount of $\mathrm{CO}_{2}$. The analysis of environmental tax revenues in the EU showed the dominance of their fiscal component over the regulatory one.
\end{abstract}

Keywords: environmental taxes, EU member states, pollution, public good, welfare economics, correlation analysis, energy tax, transport tax, pollution tax, resource tax

\section{INTRODUCTION}

The address of the corresponding author: Oleksandr Dluhopolskyi

莑=1lugopolsky77@gmail.com
Environmental policy in EU countries in the context of ecological taxes should help the society to achieve the priority of providing the "clean 
ecology" as a public good in the XXI century's welfare economy.

There are several challenges to Environmental Tax Reform in the EU, and many of them are capable of influencing household behavior. Lowincome households are particularly sensitive in this context. Some EU countries are pursuing policies that are based on "tax punishment" or aimed at raising additional funds to invest in environmental issues (Koziuk et al., 2020). The system of gross environmental taxes (TET) in the sense of improving the efficiency and protection of natural resources includes energy (ET), transport (TT), pollution (PT), and resource tax (RT). Since 2010, the emphasis on environmental regulation has shifted towards the EU 2020 strategy (Stec, Grzebyk, 2016), the main goal of which is to achieve greater consistency in the implementation of economic, social, and environmental programs.

\section{LITERATURE REVIEW}

The theoretical background of environmental taxation is based on the A. Pigou concept about using taxation to correct negative externalities, such as pollution (Pigou, 2013). A taxation is a powerful tool for tackling complex environmental issues such as climate change (Merko et al., 2018). This is especially true for developed and developing countries since environmental taxation itself is a significant element of economic growth (He et al., 2019; Kuralbayeva, 2019).

The importance of taxation as a tool to change environmental behavior is directly dependent on its effectiveness (Costantini, Mazzanti, 2012). When tax revenues are used for environmental expenditures or other taxes, these taxes are considered effective and officially supported (Anita et al., 2016). The modern development of civilization is increasingly paying attention to education and taxation, as an element of financing measures aimed at improving the environmental situation (Fullerton et al., 2010; Heine et al., 2012; Koziuk et al., 2019a).

Environmental degradation necessitates institutional reforms that would force private consumers of natural resources to bear the full burden of social costs caused by their activities (Dasgupta, Mäler, 2000).

The Paris Climate Agreement 2015, revised by the
Kyoto Protocol, with its emphasis on strengthening environmental standards, has increased interest in the topic of climate change through the likely relocation of manufacturing and foreign investment to countries with less stringent government regulation, i.e. environmental taxes (Druzin, 2016). A lot of works (Cole et al., 2017; Birdsall, Wheeler, 1993; Dunning, 1998; Panayotou, 2003) emphasize, that capital and trade will flow from countries with strict rules and high environmental taxes to countries with less stringent environmental standards and low environmental taxes, however, liberalization and openness of international trade will have a significant impact on both investment attractiveness and environmental degradation. The deregulation of environmental policy, which most often has a detrimental effect on the environment, is encouraged by "race to the bottom" in developing countries for which attracting foreign direct investment is more important than preserving the environment. In this context, it is a "short game" (Koziuk et al., 2019b). In general, environmental policy tools (subsidies, taxes) in the context of their stringency can be divided into market and non-market. Marketoriented policies are designed to combine the additional costs of market forces associated with the interaction of economic agents with pollutant containment tools, rather than setting clear guidelines, standards, or restrictions (Stavins, 2006; Koziuk et al., 2019b). In this article, we'll try to find the relationship between the stringency of environmental regulation policy (example of environmental taxes) and emissions of pollutants.

\section{METHODOLOGY}

To evaluate the connections between environmental taxes and emissions of pollutants, the article uses the method of cross-correlation analysis. This research continues the previous author's studies about the environmental measurement of welfare economics (Dluhopolskyi et al., 2019a; Dluhopolskyi et al., 2019b; Koziuk et al., 2019a; Koziuk et al., 2019b; Козюк et al., 2019; Koziuk et al., 2020).

In continuation of the previous study (Koziuk et al., 2020), we used a different methodological approach and built a regression of panel data with a fixed effect, considering the features (constants) within each EU country. Similar emission 
indicators $\left(\mathrm{CO}_{2}, \mathrm{PM} 2.5 \mathrm{mg}\right)$ were chosen as the dependent variable $(\mathrm{Y})$, and environmental taxes in millions of euros (TET, ET, TT, PT, \& RT) were selected as the independent variables $(\mathrm{X})$, as well as additional environmental indicators - RE (an indicator of the share of renewable energy in final consumption in the country) and ISO (number of businesses in the country that have an environmental certificate ISO 14001 for the period 1995-2018).

\section{RESULTS}

Environmental taxes are those designed to tax behavior that is harmful to the planet's health (Environmental taxes make way to protect the environment, 2018). They are based on a principle - those who pollute need to pay.

As mentioned in (Koziuk et al., 2020), according to the level of environmental taxes, all EU countries can be divided into few groups:

1. Countries in which the share of environmental taxes reaches $10 \%$ or more of the total tax revenue (Slovenia, Latvia, Greece).

2. Countries in which the share of environmental taxes ranges from 6 to $9 \%$ of the total tax revenue (Netherlands, Cyprus, Estonia, Denmark, Bulgaria, Malta, Italy, Romania, Czech Republic, Poland, Hungary, Lithuania, Slovakia).
3. Countries in which the share of environmental taxes is $5 \%$ or less of the total tax revenue (Austria, Spain, Belgium, Germany, Luxembourg, Sweden).

The model of the relationship between the gross environmental tax (TET) and carbon dioxide $\left(\mathrm{CO}_{2}\right)$ emissions are presented in Table 1. The empirical basis of the model included 553 observations and contained 28 groups with a general chronology of indicators for 24 years. The obtained model is statistically significant because Fisher's F-test is 36.87 with Ftab. $0.01=7.68$.

According to the results of regression analysis with panel data, we found that gross environmental taxes have an inverse statistically significant relationship with the amount of $\mathrm{CO}_{2}$ emissions into the atmosphere. An increase in the mass of fiscal revenues from all environmental taxes by $€ 1$ million results in a reduction in carbon dioxide emissions per capita of 0.0001034 tons (or 0.103 $\mathrm{kg})$. This ratio is statistically significant at a $0.1 \%$ level of test significance. The $95 \%$ confidence interval is within $[-0.0001383,-0.0000685]$. The coefficient of determination of $\mathrm{R}^{2}$ within countries is equal to 0.0927 , i.e. the variation of the dependent variable $\left(\mathrm{CO}_{2}\right.$ emissions) by $9.27 \%$ is due to the variation of the independent variable (in our case - revenues from environmental taxes).

Table 1. Regression model of the dependence between gross environmental taxes (TET, million euros/year) and carbon dioxide emissions ( $\mathrm{CO}_{2}$, tons per capita) in the EU countries

\begin{tabular}{|c|c|c|c|c|c|c|c|}
\hline \multirow{2}{*}{\multicolumn{3}{|c|}{$\begin{array}{l}\text { Fixed effects (within) regression } \\
\text { Group variable: country }\end{array}$}} & \multicolumn{2}{|c|}{ Number of obs. } & \multicolumn{3}{|c|}{$=553$} \\
\hline & & & \multirow{2}{*}{\multicolumn{5}{|c|}{$\begin{array}{l}\text { Number or groups } \\
\text { Obs. per group: }\end{array}$}} \\
\hline \multicolumn{3}{|c|}{$\begin{array}{l}\text { Group variable: country } \\
\text { R-sq: }\end{array}$} & & & & & \\
\hline \multicolumn{3}{|l|}{$\begin{array}{l}\text { R-sq: } \\
\text { within }\end{array}$} & \multicolumn{2}{|c|}{$\min$} & \multicolumn{3}{|c|}{$=13$} \\
\hline \multicolumn{3}{|c|}{ between $=0.0013$} & \multicolumn{2}{|l|}{ avg } & \multicolumn{3}{|c|}{$=19.8$} \\
\hline \multirow{2}{*}{\multicolumn{3}{|c|}{ overall $=0.0002$}} & \multirow{2}{*}{\multicolumn{2}{|c|}{$\begin{array}{l}\max \\
\mathrm{F}(1.27)\end{array}$}} & \multicolumn{3}{|c|}{$=20$} \\
\hline & & & & & \multicolumn{3}{|c|}{$=36.87$} \\
\hline \multicolumn{3}{|c|}{$\operatorname{corr}(\mathrm{u}$ i, $\mathrm{Xb})=-0.4277$} & \multicolumn{2}{|l|}{ Prob $>F$} & \multicolumn{3}{|c|}{$=0.00$} \\
\hline \multicolumn{8}{|c|}{ (Std. Err. adjusted for 28 clusters in-country) } \\
\hline $\begin{array}{l}\mathrm{CO}_{2} \\
\text { emissions }\end{array}$ & Coef. & $\begin{array}{l}\text { Robust } \\
\text { Std. Err. }\end{array}$ & $\mathrm{t}$ & \multicolumn{2}{|c|}{$P>|t|$} & \multicolumn{2}{|c|}{ [95\% Conf. Interval] } \\
\hline TET & -0.0001034 & 0.0000170 & -6.07 & 0.0 & & -0.0001383 & -0.0000685 \\
\hline cons & 9.098317 & 0.1688549 & 53.88 & 0.0 & & 8.751856 & 9.444779 \\
\hline sigma_u & 3.82477 & & & & & & \\
\hline sigma_e & 0.88366771 & & & & & & \\
\hline rho & 0.94932628 & & & no & & ance due to $u$ & \\
\hline
\end{tabular}

Source: author's calculations based on (Environmental tax revenues, 2020; EUROSTAT, 2019)

The overall indicator $\mathrm{R}^{2}$ between countries is at the level of 0.0013 , which is logical since the variance of values within individual countries is high due to the presence of individual effects of 
these countries. That is, each of the countries has a certain list of unobserved data that fall into the category of permanent individual effects in this model of panel regression, and these individual effects for countries by $94.93 \%$ determine the variance of the dependent variable $\left(\mathrm{CO}_{2}\right.$ emissions).
Similarly, the relationships between the volumes of certain types of environmental taxes (ET, TT, PT, \& RT), the share of renewable energy in final consumption (RE), the number of businesses in the country with an ISO 14001 (ISO) environmental certificate and the volumes of carbon dioxide $\left(\mathrm{CO}_{2}\right)$ emissions were analyzed (Table 2).

Table 2. Regression model of dependence between the certain types of environmental taxes (ET, PT, $R T, \& T T)$, the share of renewable energy in final consumption (RE), the number of certified facilities (ISO), and carbon dioxide $\left(\mathrm{CO}_{2}\right)$ emissions in the EU countries

\begin{tabular}{|c|c|c|c|c|c|c|}
\hline \multicolumn{4}{|c|}{ Fixed effects (within) regression } & Number of obs & \multicolumn{2}{|l|}{$=317$} \\
\hline \multicolumn{4}{|c|}{ Group variable: country } & Number of groups & & \\
\hline \multicolumn{4}{|l|}{ R-sq: } & \multicolumn{3}{|l|}{ Obs per group: } \\
\hline \multicolumn{4}{|c|}{ within $=0.4756$} & \multicolumn{3}{|l|}{$\min$} \\
\hline & avg & \multicolumn{2}{|l|}{$=15.9$} \\
\hline \multirow{2}{*}{\multicolumn{4}{|c|}{ overall $=0.0467$}} & $\max$ & \\
\hline & & & & $F(6.19)$ & \multicolumn{2}{|l|}{$=43.19$} \\
\hline \multicolumn{4}{|c|}{$\operatorname{corr}(\mathrm{u} i, \mathrm{Xb})=-0.4265$} & \multirow{2}{*}{\multicolumn{3}{|c|}{$\begin{array}{l}\text { Prob > F } \\
\text { for } 20 \text { clusters in-country) }\end{array}$}} \\
\hline \multicolumn{4}{|c|}{$\operatorname{corr}(\mathrm{u} \mathrm{i}, \mathrm{Xb})=-0.4265$} & & & \\
\hline $\begin{array}{l}\mathrm{CO}_{2} \\
\text { emissions }\end{array}$ & Coef. & $\begin{array}{l}\text { Robust } \\
\text { Std. Err. }\end{array}$ & $\mathrm{t}$ & $P>|t|$ & \multicolumn{2}{|c|}{ [95\% Conf. Interval] } \\
\hline ET & -0.0000381 & 0.0000388 & -0.98 & 0.339 & -0.0001193 & 0.0000432 \\
\hline PT & -0.0030217 & 0.0011756 & -2.57 & 0.019 & -0.0054822 & -0.0005612 \\
\hline $\mathrm{RT}$ & 0.0012553 & 0.0009872 & 1.27 & 0.219 & -0.0008111 & 0.0033216 \\
\hline TT & 0.0003930 & 0.0001530 & 2.57 & 0.019 & 0.0000727 & 0.0007133 \\
\hline $\mathrm{RE}$ & -0.1430046 & 0.0316366 & -4.52 & 0.000 & -0.2092207 & -0.0767884 \\
\hline ISO & -0.0000484 & 0.0000220 & -2.20 & 0.041 & -0.0000945 & $-2.28 \mathrm{e}-06$ \\
\hline cons & 9.8336850 & 0.5198172 & 18.92 & 0.000 & 8.7456950 & 10.92167 \\
\hline sigma_u & 2.6281104 & & & & & \\
\hline sigma_e & 0.65554558 & & & & & \\
\hline rho & 0.94142601 & 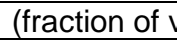 & $\mathrm{c}^{2}$ & to $u \_i$ ) & & \\
\hline
\end{tabular}

Source: Author's calculations based on (Environmental tax revenues, 2020; EUROSTAT, 2019)

The domestic indicator $R^{2}$ is 0.4756 , i.e. the variation of the dependent variable (amount of $\mathrm{CO}_{2}$ emissions) by $47.56 \%$ is due to the variation of the independent variables included in our model. The total $R^{2}$ between countries is 0.0467 . The correlation coefficient between individual errors within each country and independent variables in the regression is -0.4265 , i.e. it is high enough to use a model with fixed effects, as opposed to a model with random effects. Thus, we have a situation in which the largest impact on the dynamics of changes in the amount of $\mathrm{CO}_{2}$ has an indicator of the share of renewable energy in the final consumption of RE.

The growing demand for the public good "clean ecology" raises the question of how the economy with the given technological parameters can provide it. In this sense, environmental taxes should be primarily corrective in content. Their fiscal role should take a back seat. However, the analysis of environmental tax revenues in European countries (in terms of volume and structure) showed the dominance of their fiscal component over the regulatory one (Koziuk et al., 2020; Environmental tax revenues, 2020; EUROSTAT, 2019). Among the most important instruments of environmental policy in most EU countries, among taxes on energy, transport, environmental pollution, and resources, remain taxes on energy and vehicles, the collection of which is mainly aimed at preventing climate change.

The general trend of increasing the total value of environmental taxes in the EU for more than twenty years is accompanied by almost constant emissions of pollutants. Significant differences in 
the dynamics of fiscal revenues and emissions may hide the risk of the political and economic discrediting of environmental taxation. Difficulties in evading such taxation with a high probability of shifting the burden of such taxation to end-users lead to a change in the structure of tax revenues. But this does not guarantee that the correction of "environmental behavior" will achieve environmental preferences (Koziuk et al., 2019a; $\mathrm{He}$ et al., 2019). Most likely, fiscal revenues compensate for "environmental losses" indirectly, which makes environmental policy more sensitive to the overall efficiency of the public sector, breaking the clearer link between environmental taxation and the public good "clean ecology".

\section{CONCLUSIONS}

As a result of the study, it was empirically proved that the level of environmental taxation has a significant impact on the amount of $\mathrm{CO}_{2}$ emissions in the direction of their reduction $\left(R^{2}=-0.4277\right)$. However, the share of renewable energy in final consumption also has a significant impact on the dynamics of changes in the amount of $\mathrm{CO}_{2}\left(\mathrm{R}^{2}=\right.$ $0.143)$.

It should be noted that the "pollution tax" model has some limitations. It does not consider many other potentially important explanatory variables (GDP, population size and density, poverty level, level of ecological culture, education, forest, and green area dynamics, etc.).

\section{Acknowledgment}

The authors acknowledged the study was conducted within the [Project 0117U000412] "Ecologization in a new paradigm of the welfare state" $2017-2019$.

\section{WORKS CITED}

Anita, S., Capasso, V., Kunze, H., \& la Torre, D. (2016). Optimizing Environmental Taxation on Physical Capital for a Spatially Structured Economic Growth Model Including Pollution Diffusion. Vietnam Journal of Mathematics, (45), 199-206.

Birdsall, N., \& Wheeler, D. (1993). Trade policy and industrial policy in Latin America - where are the pollution havens. World Bank Discussion Paper, (1), pp. 159-167.

Cole, M.A., Elliott, R.J., \& Zhang, L. (2017). Foreign direct investment and the environment. Annual Review of Environment and Resources, 42(1), 465-487.

Costantini, V., \& Mazzanti, M. (2012). On the Green and Innovative Side of Trade Competitiveness? The Impact of Environmental Policies and Innovation on EU Exports. Elsevier Research Policy, (41), 132-153.

Dasgupta, P., \& Mäler, K. (2000). Net national product, wealth, and social well-being. Environment and Development Economics, 5(1), 69-93.

Dluhopolskyi, O., Koziuk, V., Ivashuk, Y., \& Klapkiv, Y. (2019). Environmental welfare: quality of policy vs. society's values. Problemy Ekorozwoju / Problems of Sustainable Development, 14(1), 1928.

Dluhopolskyi, O., Koziuk, V., Ivashuk, Y., Panukhnik, O., \& Virkovska, A. (2019). Empirical evaluation of preferences by ecological factors of the individual welfare of Ukrainians. Journal of Geology, Geography, and Geoecology, 28(1), 39-50.

Druzin, B.H. (2016). A plan to strengthen the Paris agreement. Fordham Law Review, (84).

Dunning, J.H. (1998). Location and the multinational enterprise: a neglected factor. Journal of International Business Studies, 40(1), 45-66.

Environmental tax revenues (2020). Retrieved from: https://appsso.eurostat.ec.europa.eu/nui. 
Environmental taxes make way to protect the environment (2018). Retrieved from: https://www.iberdrola.com/environment/green-and-environmental-taxes.

EUROSTAT (2019). Environmental tax statistics. Retrieved from: https://ec.europa.eu/eurostat.

Fullerton, D., Leicester, A., \& Smith, S. (2010). Environmental Taxes. Oxford: Oxford University Press.

He, P., Zhang, Y., Yuan, Y., Qiao, Y., Xin, L., \& Zou, X. (2019). The relationship between environmental taxation, environmental performance, and economic growth: a comparative study of Sweden and China 1985-2016. Ecology, 28(107), 401-410.

Heine, D., Norregaard, J., \& Parry, W.H. (2012). Environmental tax reform: principles from theory and practice to date. IMF Working Papers, (180).

Koziuk, V., Dluhopolskyi, O., Hayda, Y., \& Klapkiv, Y. (2019a). Does education quality drive ecological performance? Case of high and low developed countries. Global Journal of Environmental Science and Management, 5(S1), 22-32.

Koziuk, V., Dluhopol's'kyy, O., Hayda, YU., Ivashuk, YU., Shymans'ka, O., Voz'nyy, K., \& Dluhopol's'ka, T. (2019). Ekolohichnyy vymir derzhavy dobrobutu: monohrafiya. K.: Lira-K, 224 p.

Koziuk, V., Hayda, Y., Dluhopolskyi, O., \& Klapkiv, Y. (2019b). Stringency of environmental regulations vs. global competitiveness: an empirical analysis. Economics and Sociology, 12(4), 264-284.

Koziuk, V., Hayda, Y., Dluhopolskyi, O., Martynyuk, V., \& Klapkiv, Y. (2020). Efficiency of environmental taxation in European countries: a comparative analysis. Naukovyi Visnyk Natsionalnoho Hirnychoho Universytetu, (5) (in progress).

Kuralbayeva, K. (2019). Environmental taxation, employment, and public spending in developing countries. Environmental \& Resource Economics, 72(4), 877-912.

Merko, F., Dursun, S., \& Merko, F. (2018). Environmental taxation - the effects on environmental effectiveness and economic efficiency. International Journal of Ecosystems and Ecology Science, 8(4), 739-746.

Panayotou, T. (2003). Economic growth and the environment. Economic survey of Europe / Ed. United Nations Economic Commission for Europe. New York: United Nations Publishing.

Pigou, A. (2013). The Economics of Welfare. London: Palgrave Macmillan.

Stavins, R. (2006). Market-based environmental policies: what can we learn from U.S. experience (and related research)? Moving to markets in environmental regulation. Oxford University Press.

Stec, M., \& Grzebyk, M. (2016). The implementation of the Strategy Europe 2020 objectives in European Union countries: the concept analysis and statistical evaluation. Quality and Quantity, 52(1).

Received for publication:

Revision received:

Accepted for publication:
12.09.2020

29.11 .2020

30.12 .2020

\section{How to cite this article?}

Style - APA Sixth Edition:

Koziuk, V., Dluhopolskyi, O., \& Voznyi, K. (2021, January 15). Environmental taxes and emissions of pollutants in the EU: Empirical analysis. (Z. Cekerevac, Ed.) MEST Journal, 9(1), 68-74. doi:10.12709/mest.09.09.01.09 
Style - Chicago Sixteenth Edition:

Koziuk, Viktor, Oleksandr Dluhopolskyi, and Kazymyr Voznyi. 2021. "Environmental taxes and emissions of pollutants in the EU: Empirical analysis." Edited by Zoran Cekerevac. MEST Journal (MESTE) 9 (1): 68-74. doi:10.12709/mest.09.09.01.09.

Style - GOST Name Sort:

Koziuk Viktor, Dluhopolskyi Oleksandr and Voznyi Kazymyr Environmental taxes and emissions of pollutants in the EU: Empirical analysis [Journal] // MEST Journal / ed. Cekerevac Zoran. - Belgrade Toronto : MESTE, January 15, 2021. - 1 : Vol. 9. - pp. 68-74.

Style - Harvard Anglia:

Koziuk, V., Dluhopolskyi, O. \& Voznyi, K., 2021. Environmental taxes and emissions of pollutants in the EU: Empirical analysis. MEST Journal, 15 January, 9(1), pp. 68-74.

Style - ISO 690 Numerical Reference:

Environmental taxes and emissions of pollutants in the EU: Empirical analysis. Koziuk, Viktor, Dluhopolskyi, Oleksandr and Voznyi, Kazymyr. [ed.] Zoran Cekerevac. 1, Belgrade - Toronto : MESTE, January 15, 2021, MEST Journal, Vol. 9, pp. 68-74. 